\title{
Augustein SCHUBINGER AND THE ZINCK: INNOVATION IN PERFORMANCE PRACTICE
}

\section{Keith Polk}

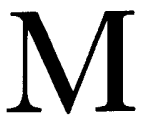

y interest was first drawn to Augustein Schubinger some 15 years ago, while working in the Belgian National Archives in Brussels. At that time, not much had been established concerning important specifics of instrumental performance practice, and I was seeking information on such matters as the constitution of ensembles (the most important of which was the one of trombones and shawms), the training of the players and the nature of their repertory. In documents listing numerous players of loud instruments, I had found large numbers of shawmists and trombonists, but engaged in the usual performances in processions, for banquets, at weddings, etc. In the midst of all this, however, appeared a mention of one "Master Augustin" (a cornetto player), who had performed during a celebration of high mass in Mechelen in 1501.' From the context of the reference, it seemed that Augustin was a professional wind player. This entry, though, was unusual on several counts. It indicated that Augustin was playing within the liturgy itself, and this was the earliest mention of such performance I had found. It also appeared certain that this player performed with singers, and suggested (given the conditions of such performances) that he could read music. Earlier, in the
15 th century, the convention of distinctions between loud and soft instruments had apparently been quite rigid. Wind players did not perform within the liturgy, they did not perform with singers and, apparently, they did not read music.

This Augustin, then, was a remarkable performer in several ways. I suspected that he was probably the Augustine "Sobinger" who was employed by Philip the Fair, and who appeared in several cities in the following years, as in Brussels in 1505 and Constance in $1510 .^{2}$ Another German musician, Hans Nagel, had exhibited the same unusual range of performance activity. Nagel, a trombonist, had played in a series of liturgical appearances in $1509 .^{3}$

Several years later, while in Florence, I came across Augustein (to give the spelling he evidently preferred) again. Though studying Italian instrumental practices of the late 15 th and early 16 th centuries, I became intrigued by the presence throughout northern Italy of German players. This was the case in Ferrara, Milan and Mantua, but was especially clear in Florence. The civic ensemble of 1445 was exclusively German, and, in fact, the abilities of these players was so impressive that the city council enacted a statute specifying that henceforth the ensemble was to be "foreign," i.e. German.

Music historian Keith Polk specializes in music of the Renaissance and teaches at the University of New Hampshire. He is writing a book on 15th-century German instrumental music. 
Among other similar registers of city acts concerning musicians was an extraordinarily detailed record of the appointment of a trombonist in 1489; the player named was "Magister Augustin" of Augsburg. His services were clearly highly prized by the city, for his salary was very high. ${ }^{4}$ While the name Augustine was not rare, it was not a common one, either. Furthermore, the term master was seldom accorded to wind players, and it seemed likely the Florentine master was the same as the one encountered in Mechelen.

More important, it became clear that, for the period c. 1450-1520, German players were setting the pace. In Ferrara there was Michele Tedesco (active from about 1480-1520), while in Mantua a famous player about 1500 was Enrico Tedesco, trombone. In Florence, there was Augustin - who may have been the same as the Augustine who appeared throughout northern Europe just after the turn of the century. Obviously, any further understanding of instrumental music hinged on further research in Germany.

Three years ago I was able to spend several months in Germany, and through studying the extensive documents in the Augsburg City Archive, have been able to establish at least the main outlines of the career of this quite brilliant musician. Augustein's biographical background will be described first, then his career in terms of the impact he and his peers had on performance practice of instrumental music.

\section{Augustein and}

\section{the Schubinger family}

The story begins, insomuch as documentation permits, in 1457, with the appointment to the Augsburg city ensemble of a new player, "Ulrich pfyffer von
Lantsberg,"5 who was Augustein's father. Ulrich must have been a very fine player, for later he, too, was termed "master," and became quite wealthy. He was also, as we shall see, the father not only of Augustein, but of several musical sons. In 1471 , Ulrich was recruited to join the musical forces of the duke of Austria in Innsbruck. ${ }^{7}$ He was there from 1471 to 1474 , and returned to his post in Augsburg in 1477. (I have been unable to trace his activities between 1474 and 1477 , although I suspect he was in Italy laying the groundwork for the subsequent careers of his sons.) Ulrich remained in Augsburg for the rest of his life, dying there about $1492 .^{8}$

The oldest son, Michel, first appeared in Augsburg records in 1469, when he received one of the salary payments for his father. ${ }^{9}$ Michel traveled with his father to Innsbruck in 1471, but was evidently back in Augsburg by 1472, and took over his father's place in the city ensemble by 1473 at the latest. ${ }^{10}$ Michel left the city for good in 1477 , bound for Italy, and with his departure comes the first appearance of the family name in the Augsburg accounts. This was in conjunction with the quite extraordinary gesture made by the city, which was to extend to him the gift of an instrument: "Michael Schubinger ... a ain pfeiffen geschänkt." Michel joined the court ensemble at Ferrara, where, as Michele Tedesco, he became one of the most prominent musicians in northern Italy. ${ }^{12}$

The departure of Michel created a vacancy in the Augsburg ensemble, and the accounts for 1477 indicate that this was filled by another of Ulrich's sons. The salary lists for 1477 do not specify the name of Michel's replacement, but livery subsidy was paid to both Ulrich and to "seine Sun für ain claid."13 Unfor- 


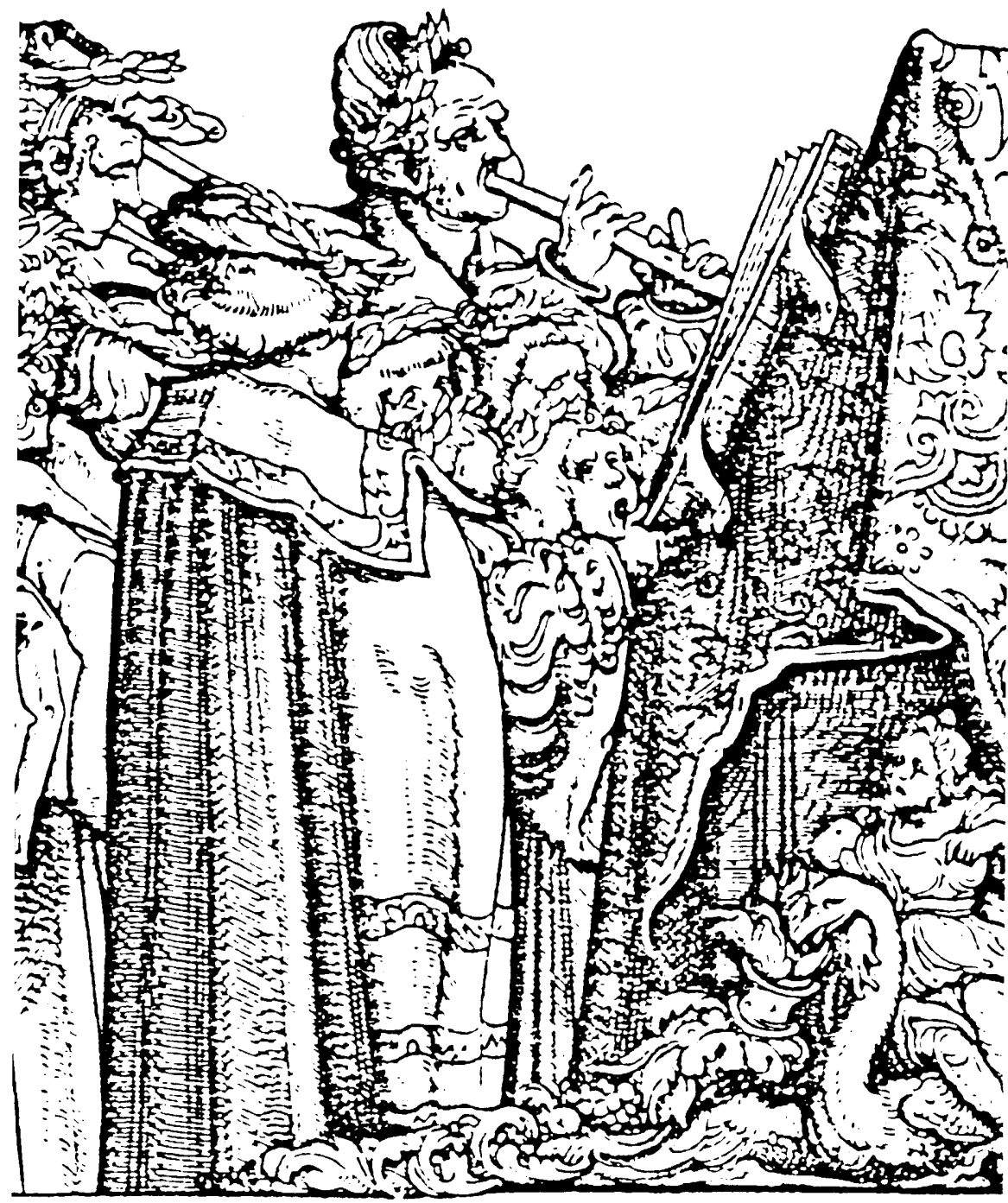

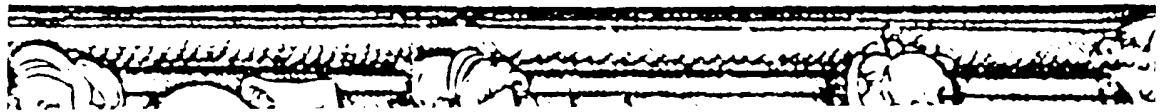

Fig. 1: Augustein Schubinger in actual performance, from the Triumphs of Maximilian. Augustein is shown playing the cornetto, and appears to be shown with the mouthpiece centered on the embouchure, not off to the side. 
tunately, the accounts from 1478 to 1481 are not extant, but in the next surviving volume, that of 1481 , Augustein Schubinger appears as a member of the civic ensemble. ${ }^{14}$ The son mentioned in 1477, then, was probably Augustein, and I assume he would have appeared on full salary in the accounts for 1478 had they survived. ${ }^{15}$

Given this first appearance c. 1477, we can assume that Augustein was born about 1460 . And while the name Augustein was occasionally to be found for musicians at this time, perhaps even the naming of this son itself confirms a probable birthdate. The naming may have been a gesture of respect to the city by Ulrich, newly arrived into the "Augusta Stadt," as Augsburg did, and still does, like to style itself.

In 1481 , his salary was 24 florins, befitting a junior member, but in 1482 this was raised to 36 florins. ${ }^{16}$ During this same year, he and his father were joined by yet another Schubinger son in the town group, Ulrich the younger. Normally the scribes listed the various members of the family only by their first name and by their professional function as Stadtpfeifer, a common procedure when dealing with men of lower artisan classes. The following year, 1483, was the first in which the Baumeisterbiucher granted the family the honor of listing their names in full. ${ }^{17}$

Early in 1484, Augustein left the city for a brief period of service with the margrave of Brandenburg, but had returned by the end of $1485 .{ }^{18}$ The city was undoubtedly delighted to see him return, for the house of Brandenburg for decades had been a bitter enemy of Augsburg and other of the imperial cities. This dalliance with Brandenburg by one of Augsburg's brightest young talents, which must have been galling to the town fathers, might have been yet another example of the manner in which the family furthered its interest through connections. During the years 1481-85, conditions were tense in Ferrara, and Michel seems to have left the court for a time. In Nördlingen, in 1483, the city council provided a grant to the pfeiffer ensemble of the margrave of Brandenburg-one of the players was a "Michel." No surname is given, but it seems likely that this was Augustein's brother. This likelihood is further supported by the fact that both returned to their former posts (in Ferrara and Augsburg, respectively) in $1485 .^{19}$

While Augsburg had provided an adequate environment for the senior Ulrich, Augustein was not content to limit his artistic horizons by permanent ties to his native city. He was recruited to join the musical forces of the imperial household in 1487 , where he remained until 1489 . In that year, a vacancy had developed in the civic ensemble in Florence (with the death of their German trombonist, Magister Johannes). The recruiting net was thrown quite wide, and Lorenzo the Magnificent himself entered into the matter. Augustein had been recommended to Lorenzo, who, through channels, let it be known that he wished to engage this fine northern player. Augustein had been in Milan in February, but as negotiations were in progress he was not in Italy. His brother Michel joined the process, corresponding with Lorenzo to assure him that Augustein would soon return to Ferrara and would be able and willing to come to Florence. ${ }^{20}$ Later in that year, Augustein did move to Florence, where he remained until 1493 or 1494. Lorenzo died in 1492, and with his death the political situation in the city deteriorated. With the ascendancy of the Savanarola faction, whose domestic 
political program included a systematic attack on worldly pleasures (including music), conditions for music were hostile. In any event, Augustein returned to the service of the Hapsburg court, an alliance which he would maintain until the end of his life. ${ }^{21}$ Heinrich Isaac, it should be noted, made the same move at precisely the same time, almost certainly for the same reasons.

Augustein's contract with the court was, it appears, a flexible one. He spent several years, until just after 1500 , centered in Innsbruck in the service of Maximilian I. Then began, in about 1501 , several years of service with Philip the Fair, Maximilian's son. Philip was acting as the figurehead of Hapsburg authority in the Low Countries-and in Spain, after the marriage of Philip and Joanna of Spain, and the death of all others with more direct claim to the Spanish throne. Philip's power base was never secure, and he had to travel frequently throughout his dominions to attempt to shore up political alliances-and Augustein frequently joined the retinue, performing an important role in festive, ceremonial occasions when the magnificence of Philip's court was calculated to impress his subjects. As a cornetto player, he was evidently astonishingly talented, for he is repeatedly mentioned by contemporary observers, and it was undoubtedly because of his abilities to contribute to Philip's political image that Maximilian was willing to give him extended leave from the imperial band proper. We have records of Augustein in various cities of the Low Countries, Spain, and of ceremonial visits to the German seat of imperial authority. The years with Philip extended from about 1501 to 1506, after which he returned to Innsbruck. ${ }^{22}$ Even during this first decade of the century, however, Augustein seems to have been associated for a time with the Gonzaga court, especially early in 1505 . His younger brother (Ulrich the younger, styled Enrico trombone in Mantua) was on what turned out to be a long-term contract there, and was joined for a time by Augustein. ${ }^{23}$ Throughout this decade, Augustein also maintained a residence in Augsburg, and continued to appear in Bavaria, where he was normally mentioned as a member of the imperial band.

From 1506 until his death in 1532, he was more exclusively in the employ of the Hapsburg court in Austria. He was noted on numerous occasions in official visits to Augsburg and other cities in $\mathrm{Ba}$ varia. He was granted a pension, which was to provide him income for the remainder of his life, in 1523. He appeared regularly in the accounts of Augsburg until 1531. During this year, ominous mention of illness enters the records, and he died in $1532 .{ }^{24}$

\section{Augustein and performance practice}

As a young player in Augsburg, Augustein was referred to as a pfeiffer. The most precise translation of the term would be shawmist, although "professional wind player" conveys more the actual meaning of the term. That is, while it was clear that for wind players c. 1450 the shawm was the primary professional instrument, all such players were expected to double on a fairly wide range of instruments. These instruments included the shawm (and bombard), trombone, trumpet, bagpipe and recorder. The one limiting factor was that these instruments were of the loud category, with the exception of the recorder. ${ }^{25}$

By 1484 , Augustein was specified as a player of trombone, and this instrument probably remained central to his playing 
career thereafter. It was certainly as a trombonist that he came to the attention of Lorenzo the Magnificent, and subsequently moved to Florence. As a trombonist, then, he specialized in the contratenor range. Such specialization by range was, of course, characteristic of wind players in the 15 th century. ${ }^{26}$

Soon after his return from his Florentine sojourn, his career began to broaden. A cornetto player who was with Maximilian performed in Basel in 1495/6; this may have been Augustein, and he was certainly playing this instrument on a series of occasions between 1501-1506. ${ }^{27}$ As mentioned above, what is remarkable is the context of these performances, for here we see a player from the German Stadtpfeifer tradition playing with singers, in liturgical performances and in settings where the ability to read music was almost certainly a given.

This was not the limit of Augustein's flexibility, for at about the same time he also began to style himself a player of the lute. In listings of the personnel for one of Philip's visits to Spain, Augustein is listed as a player both of lute and cornetto. ${ }^{28}$ During his short stay in Mantua, his performances seem to have been almost exclusively on the former instrument. From then until the end of his career, he would occasionally be mentioned as a lutenist. We have no more precise information on his abilities, and while he may have been a skilled player, it seems doubtful that he was a virtuoso. Maximilian, at any rate, had a small band of lutenists, and Augustein was not normally included with them.

The mastery of a stringed instrument, and the cornetto (with the performance practices implied), indicate that the traditional more rigid demarcation between the performance practices of loud and soft ensembles, and loud and soft per- formers, had disintegrated. Fundamental changes had taken place, and German players were at the forefront of these developments. A seminal figure in all this was clearly Augustein.

By at least 1490 , then, outstanding trombone and cornetto players were performing liturgical music, with singers. Note that these were still probably individual players (sometimes two performers are mentioned). That is, the shawm ensemble was not yet incorporated as a unit into vocal performances. Furthermore, the players mentioned are, in a majority of cases, trombone players. That is, in the early transitional stages, as new practices evolved, trombonists (and trombonists doubling on cornetto) seem to have been the performers most observed and mentioned.

The fact that only one or two players were involved in the combined instrumental/choral performances deserves special comment, as this points up an important question: what role did these musicians play? In modern performances of music of the period 1480-1520, one would be tempted to assign to the trombone long-note cantus firmus parts-but this hardly seems likely to have been the role of splendid players of the Schubinger mold. Furthermore, if this had been the part played, it is highly improbable that the performances would have attracted such widespread attention.

These fine musicians played prominent parts, and discant and contratenor would have been more suited to their abilities. That this was the expectation is seconded by one of the very rare accounts that is specific on the matter, from Bergen op Zoom. There, in 1519, the authorities granted a payment to Christoffe, a trombonist, because he had played contratenor with the singers ("van dat hij bascontre metten sanghers 
... gespeelt heeft"). Included in the same set of payments is one to Roeland, a wind player, "because he played the zink [also with the singers]" ("Roeland ... omdat hij metter sincken speelt"). ${ }^{29}$ In the Bergen op Zoom performances, then, Christoffe played contratenor, and Roeland, playing cornetto (almost certainly in this case a soprano instrument), probably performed the discant.

This appears reasonably specific, but still left options open to the players, because attitudes in those decades to "original text" were quite flexible. Christoffe, for example, could have played a part as written, or he could have added ornamentation. Furthermore, it is possible he improvised an entirely new contratenor. Still, given the closest reading of the account entry in Bergen op Zoom, on some occasions Christoffe probably played a written motet by a composer such as Jacob Obrecht (a native of the city) as written. ${ }^{30}$

One implication of Augustein's capability on lute concerns wind players' relationship to stringed instruments in general. Michel Schubinger also played lute, and viol as well. ${ }^{31}$ One of the dominant new strains of musical activity just after 1500 was that of bowed stringed instruments; first the viol, then, soon after, the violin. By the third decade of the 16th century, stringed ensembles began to assume a more central role, and as this occurred, many of the leading players were drawn from the ranks of wind musicians. A clear example of this was the case of Caspar Egkern, who was one of the players in the first ensemble for viols assembled for Maximilian I in about 1515. He had earlier been noted as a trombonist. ${ }^{32}$

The versatility of Augustein is further demonstrated in that he was also known to have been a composer, although no pieces specifically ascribed to him have survived.$^{33}$ We have known, of course, of musical collections that were closely tied to wind players. The Casantense manuscript has been linked to the wind band of Ferrara in 1480 (incidentally, just after Michel joined the court) ${ }^{34}$ Some of the repertory in the Augsburg Liederbuch from just after 1500 was tied to Jacob Hurlacher, a member of the Augsburg band, and a successor to Ulrich Schubinger. ${ }^{35}$ In the following generation, the most graphic example of the success of German wind players as editors and compilers was Tielman Susato of Antwerp. Susato, a native of Cologne, had begun his career in Antwerp as a trombonist in the civic band. ${ }^{36}$

A more dramatic development, and another one for which Augustein provided the model, came with the composers and families of composers/musicians linked to the wind tradition. Susato was a composer as well as an editor, and Hans Leo Hassler was for a time a member of the Augsburg civic band. ${ }^{37}$ The name Scheidt appeared in various Bavarian records in the 15 th century, and as early as 1401 a Bak (Bach?) was recorded in the town band of Nördlingen. ${ }^{38}$ Among these great families of players, none shone brighter in their day than the Schubingers.

The most dramatic changes in performance practice were mirrored in accounts from about 1500 , but this dating is certainly at least a decade or two too late. Augustein was noted as a cornetto player in 1501, when he would have been about 40 years old. It seems improbable that he would have picked up a new instrument at that age, and, indeed, one suspects that he would have learned instrumental skills in his apprentice years, with his father, about 1470. Michel, too, would probably have learned the basic techniques on stringed instru- 
ments not in the 1490s (when he was nearing 50$)$, but about 1460 , when he would have been learning-also from his father. In addition, Hans Nagel would have acquired basic contrapuntal and reading skills from his father (a "master" as was Ulrich the elder) about 1470. If they learned their skills, it would follow that the fathers, too, could practice what they were teaching. An admittedly speculative suggestion would be that a group of skilled German players set in motion new approaches to performance practice between about 1450 and 1470 . Younger players who devel- oped around 1475 put these into practice, and the changes were widely recognized by 1500 .

What is not speculation is that Augustein Schubinger, whose performances were admired in the far corners of Europe, was the first player of the cornetto to attain international stature. Furthermore, in the career of this one musician we see strands of activity that provided models for future generations for the most important subsequent developments in instrumental music. His abilities were of an order that command our respect to this day.

\section{Notes}

1. The entry is from Brussels, Belgian National Archive, \#41281, f. 192' (City Accounts of Mechelen, 1501); "Gegeven Meester Augustin van dat hy speeld ter hoo[g]missen."

2. For the appearance in Brussels, see Edmond Vander Straeten, La musique aux PaysBas avant le XIXe siècle VII (Brussels, 1867-1888), p. 170, for Constance see Gerhard Pietzsch, "Musik in Reichstadt und Residenz am Ausgang des Mittelalter," Jahrbuch für Geschichte der oberdeutschen Reichstädte, Esslinger Studien, Band 12/13 (1966-67), p. 96-97.

3. Vander Straeten, La Musique aux Pays-Bas, VII (1867-1888) p. 269.

4. Keith Polk, "Civic Patronage and Instrumental Ensembles in Renaissance Florence," Augsburger Jahrbuch für Musikwissenschaft III (1986), p. 51-68.

5. Augsburg, Stadtarchiv, Baumeisterbücher (hereafter abbreviated BB), f. 112'.

6. Concerning the term master see BB, $1484 \mathrm{f} .60$. In the same year he paid a tax of one florin, which would have placed him in the top 15 percent of the taxpayers in the city; see Keith Polk, "Instrumental Music in the Urban Centres of Renaissance Germany," Early Music History VII (1987), p. 179.

7. W. Senn, Musik und Theater am Hof zu Innsbruck (Innsbruck, 1954), p. 7.

8. Keith Polk, "The Schubingers of Augsburg; Innovation in Renaissance Instrumental Music," forthcoming in the Festschrift for Franz Krautwurst, edited by F. Brusniak, see Appendix, Table I.

9. BB, 1469 , f. 79'; a payment to Ulrich is noted as received by Michel (" $R$. michel sein sun").

10. Augsburg, Stadtarchiv, Steuerbuch, 1472, "vom Ross" quarter tax records list Michel; see BB, 1473 , f. $65^{\prime}$ for salary (the Baumeister accounts for 1472 do not survive).

11. BB, 1477, f. 92 '.

12. Concerning Michel Schubinger in Ferrara see Lewis Lockwood, Music in Renaissance Ferrara (Cambridge, 1984), p. 321-326.

13. BB, 1477, f. 72.

14. BB, 1481 , f. $64^{\prime}$.

15. Augustein did not appear in the tax rolls after 1477 , but then, oddly, he never seems to have been subjected to the city tax. His first sure appearance in the tax listings is through an assessment made of his wife's property as a resident of the city in 1495; Augsburg, Stadtarchiv, Steuerbuch, 1495, f. 14c. 
16. BB, 1482 , f. 62 '.

17. BB, 1483 , f. 53 '.

18. For notice of the departure for Brandenburg see Augsburg, Stadtarchiv, Ratsprotokol, \# 10, 1484, f. 124.

19. For Michel in Nördlingen, see Norrdlingen, Stadtarchiv, Kammerrechnungen, 1483, f. 31. For information on Ferrara, see Lockwood, Renaissance Ferrara, 322.

20. Bianca Becherini, "Relazioni di musici fiamminghi con la corte dei medici," La Rinaschita 4 (1941), p. 106-108.

21. Polk, "Civic Patronage," p. 59.

22. Polk, "The Schubingers of Augsburg," Appendix, Table III.

23. This information is from William Prizer, Power and Pleasure, forthcoming from Oxford University Press, Chapter 4.

24. F. Overton, Der Zinck (Mainz, 1981), p. 51.

25. For more on this point see Keith Polk, "Ensemble Instrumental Music in Flanders," Journal of Band Research 11 (1975), p. 18.

26. Concerning the trombone in the contratenor range see Polk, "Ensemble Music," $p$. 17-18.

27. Polk, "The Schubingers of Augsburg," Table III.

28. Vander Straeten VII (1887-1888), p. 149.

29. Korneel Slootmans, "De Hoge Lieve Vrouw van Bergen op Zoom," Jaarboek van de Oudheidkundige Kring "de Ghulden Roos" te Roosendaal, 25 (1965), p. 212.

30. Another small point relating to performance practice is that we do have one illustration of Augustein Schubinger in actual performance (see Fig. 1) from the Triumphs of Maximilian. Augustein is shown playing the cornetto, and appears to be shown with the mouthpiece centered on the embouchure, not off to the side.

31. William Prizer, "Bernardino Piffaro e i pifferi e tromboni di Mantova." Rivista Italiana di Musicologica, 16, (1981), p. 163.

32. On Egkern, see Keith Polk, "Vedel and Geige-Fiddle and Viol, German String Traditions in the 15th Century," forthcoming in the Journal of the American Musicological Society.

33. Polk, "The Schubingers," Table III.

34. Lockwood, Renaissance Ferrara, p. 224-225.

35. The manuscript is the $2^{\circ}$ Codex 142a in the Staats- und Stadtbibliothek Augsburg. A note in a contemporary hand on f. 24 mentions "Der Ersam und weisen jacob statpfeyffer," which refers to Jacob Hurlacher, the elder, who was a city musician in Augsburg in the early years of the 16th century. Louise Jonas, in Das Augsburger Liederbuch (Munich, 1983), vol. I, p. 39, reads this as merely a practice scribble by the scribe, and makes a case that the manuscript, in fact, has no relationship to Hurlacher. In the reading of the note, however, she neglects to add several key words appearing in the manuscript, for the scribe goes on to say (following the above phrase) "sol mir daf[ür] Vernnom[men]." This seems a bit garbled, but I believe the sense of it is that "Jacob Hurlacher, city shawmist, is the source of this." Whether this refers to the piece on this page "Dies est letitie," or for several pieces in this section of the manuscript is unclear. In any case, it would appear likely that Hurlacher had a packet with a piece or pieces for ensemble that he passed on the compiler of the collection.

36. On Susato see Kristine Forney, "New Documents on the Life of Tielman Susato, Sixteenth-century Music Printer and Musician," Revue belge de musicologie 36-38 (1982-84), p. 18-52.

37. Adolf Layer, "Augsburger Musikkultur der Renaissance," Musik in der Reichstadt Augsburg (Augsburg, 1965), p. 68.

38. A Hains Bak (Bach?) was a city shawmist in Nördlingen in 1401; Nördlingen, Stadt- 
archiv, Kammerrechnungen, 1402, f. 30'; a Clement Bach, a shawmist with the bishop of Passau, was in Augsburg in 1487; BB, f. 16'; a Conrad Schei[d]t was a city musician in Nördlingen in 1449; Kammerrechnungen, f. 110.
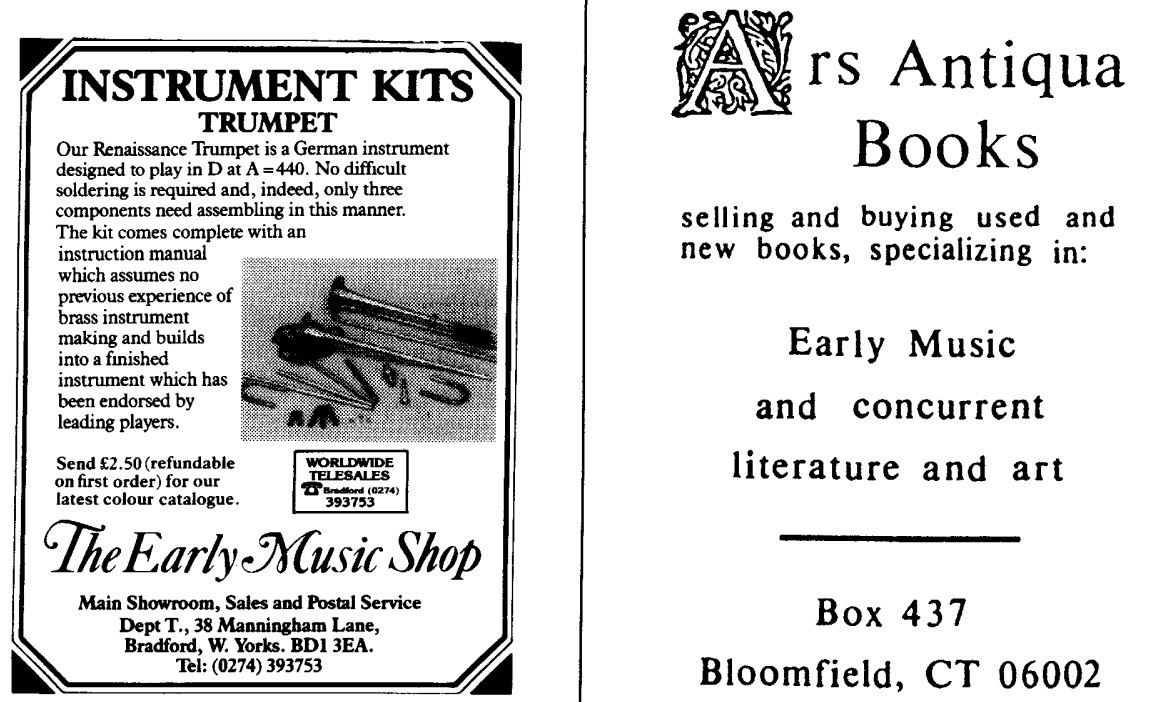

selling and buying used and new books, specializing in:

\section{Early Music}

and concurrent

literature and art

Box 437

Bloomfield, CT 06002

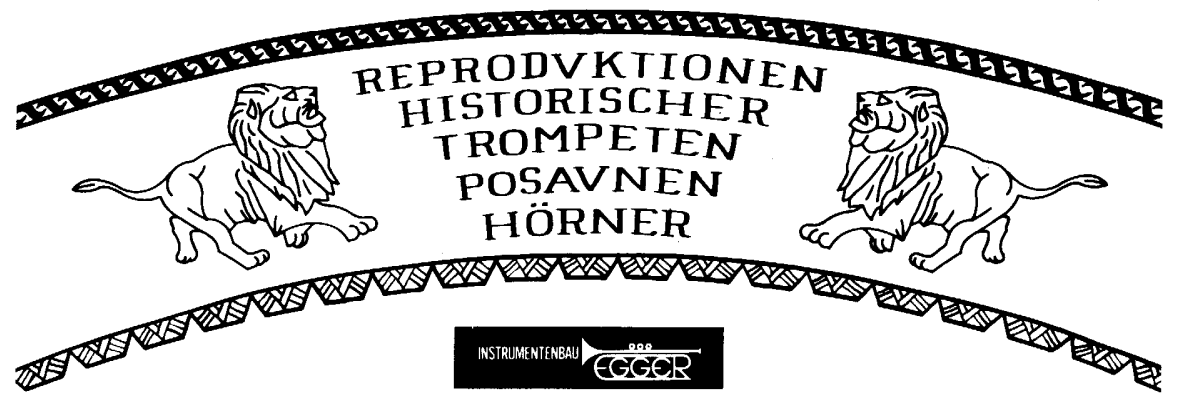

A. Egger, Turnerstr. 32, CH-4058 Basel Schweiz, Tel. 0616814233 